\title{
PLURALIDADES E (DES)QUALIFICAÇÕES
}

\author{
Antonio Carlos Dias Junior ${ }^{1}$ \\ Wenceslao Machado de Oliveira Junior ${ }^{2}$
}

O historiador inglês da intelectualidade francesa Tony Judt, em um de seus ensaios, lembra que Hannah Arendt, ao visitar Paris em 1952, teria dito que o escritor Albert Camus seria "sem dúvida, o melhor homem neste momento na França. É claramente superior aos outros intelectuais". ${ }^{3}$ Um dos heróis da Resistência francesa, editor de Combat, jornal mais influente na França pós libertação, autor de obras como O mito de Sísifo (1942) e O estrangeiro (1942) - que Ihe valeriam o Nobel de literatura em 1957 (três anos antes de sua morte prematura aos 46 anos) - Camus encarnou por algum tempo, na Paris intelectual de sua época, a imagem do homem cuja retidão moral e engajamentos políticos o colocavam na condição de intelectual público, cujo epítome definitivo seria outro filósofo de sua geração, Jean-Paul Sartre.

Acontece que o prestígio de Camus, a voz de uma geração, logo seria colocado em xeque. Do intelectual engajado da Resistência, passando pela figura do maîtrepenseur do imediato pós-guerra, o outrora herói se tornaria, muito rapidamente, um artista desiludido e um frustrado pensador das candentes questões políticas que animavam a Rive Gauche parisiense. Como bem observa Judt, Camus esteve sempre pouco à vontade com as modas intelectuais parisienses; primeiramente catalogado como "existencialista" (sobretudo após a publicação de $O$ estrangeiro) em função do tema do absurdo da condição humana que glosou a existência do protagonista do romance, negou em diversas oportunidades tal filiação.

\footnotetext{
${ }^{1}$ Editor científico. Docente - Faculdade de Educação. Universidade Estadual de Campinas (UNICAMP) Campinas, SP. Brasil. E-mail: acdiasjr@gmail.com acdiasjr@gmail.com

${ }^{2}$ Editor científico. Docente - Faculdade de Educação. Universidade Estadual de Campinas (UNICAMP) Campinas, SP. Brasil. E-mail:

3 JUDT, Tony. $O$ peso da responsabilidade. Blum, Camus, Aron e o século XX francês. Rio de Janeiro: Objetiva, 2014, p. 125.
}

\begin{tabular}{|c|c|c|c|c|}
\hline (C) ETD- Educação Temática Digital & Campinas, SP & v.20 & n.1 & jan./mar.2018 \\
\hline
\end{tabular}


Depois, quando de sua incursão mais direta no debate político-ideológico, com a publicação de $O$ homem revoltado (1951), Camus romperia definitivamente com a esquerda francesa à qual era associado embora nunca totalmente convertido (em especial, com Sartre e Simone de Beauvoir) ao atacar as bases do mito revolucionário e seu consequente terror intrínseco. Assim, à violência totalitária praticada na União Soviética e demais países comunistas, tida como inevitável e mesmo justificável, Camus oferece a imagem da revolta como condição ontológica que visa o "apelo humano e o silêncio despropositado do mundo". 4

Insuficientemente revolucionário para a esquerda e demasiadamente progressista para o oposto do espectro político (com o qual nunca teve qualquer afinidade), Camus, no curto espaço de duas décadas, experimentou o mais alto reconhecimento em um ambiente no qual a função do escritor se confundia com a do intelectual engajado para, em seguida, ser relegado à condição olvidada (em termos filosóficos e políticos) destinada àqueles que nadam contra a corrente ou que preferem simplesmente se calar.

Camus não foi, por assim dizer, um homem de ação, mas de ideias, e embora tivesse formação filosófica, via-se e apresentava-se apenas como um escritor. Inserido em um ambiente altamente hierarquizado e elitizado, foi fruto das oportunidades de escolarização propiciadas pela Terceira República francesa, cujo sistema (público) de ensino concedeu bolsas de estudo competitivas àqueles alunos que se destacavam, mas não gozavam das credenciais reservadas às elites.

Nascido no seio de uma família sem posses numa Argélia ocupada e sem ter cursado os melhores liceus (foi bolsista em um liceu em Argel) ou uma grande école parisiense (estudou na Universidade de Argel), Camus via-se indelevelmente inferiorizado quando confrontado pelos filósofos-herdeiros franceses de sua geração, ainda que se orgulhasse da formação e das oportunidades que tivera. Sartre, Aron, Merleau-Ponty, Beauvoir e Mounier constituem apenas alguns dos exemplos do peso que a origem social acarreta nos destinos

\footnotetext{
${ }^{4}$ CAMUS, Albert. O mito de Sísifo. Ensaio sobre o absurdo. São Paulo: Exilados dos livros, s/d, p. 21.

$\begin{array}{llllll}\text { (C) ETD-Educação Temática Digital } & \text { Campinas, SP } & \text { v.20 } & \text { n.1 } & \text { p. 1-4 } & \text { jan./mar.2018 }\end{array}$
}


escolares - e, por consequência, nos próprios padrões simbólicos de sociabilidade e distinção dele derivados.

Poderia um escritor de inequívoco talento literário, avatar de uma geração que resistiu à ocupação, fazer jus ao prestígio reservado aos ocupantes do Olimpo intelectual francês sem gozar das devidas credenciais escolares? Qual oceano separava, no início da década de 50, a apreciação de uma observadora estrangeira como Hannah Arendt daquela de Sartre segundo a qual o autor de $O$ homem revoltado seria o mais puro testemunho de "incompetência filosófica" glosada por "contornos de raciocínio fraco, obscuro e confuso"?

Evidentemente, há aspectos políticos, literários e intelectuais (e também pessoais) que contribuíram para o deslocamento de Camus do mainstream intelectual francês - do qual, em alguma medida, ele próprio se auto exilou - e que não caberiam ser discutidos aqui. Contudo, gostaríamos de trazer à baila algumas questões que, embora deslocadas temporal, cultural e geograficamente, servem de pontos de inflexão a partir do destino reservado a Camus na França: em que medida o ser humano - suas capacidades, limites, percepções e intermináveis possibilidades de configuração e reconfiguração - deve ser objeto de catalogação externa? Quanto de nossas escolhas intelectuais e políticas (ou a falta delas) deveria constituir regras à censura ou antes expressar a pluralidade das formas de entendimento do universo societário? Quando as instituições de ensino encerram (ou refletem) padrões que contribuem para a cristalização das hierarquias sociais ao invés de combatê-los?

No Brasil, temos vivenciado cotidianamente, mais de meio século depois, a situações que em muito se assemelham a de Camus: indivíduos e grupos sociais de pertencimentos diversos que, por expressarem determinados pontos de vista e vivências, são colocados à margem do debate público ou, muitas vezes, deliberadamente perseguidos. Não à toa,

\footnotetext{
${ }^{5}$ SARTRE, Jean-Paul. Réponse a Albert Camus. LesTempsModernes, 82, agosto de 1952, pp. 90-126. Citado por Tony Judt. $O$ peso da responsabilidade... op. cit., p. 142.

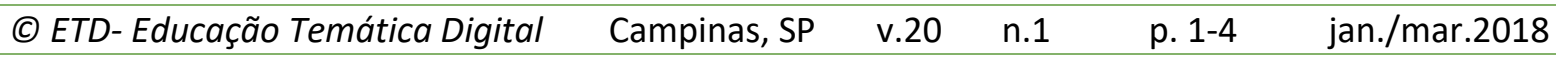


assistimos ao recrudescimento de posições conservadoras que tentam anular direitos que imaginávamos estabelecidos, sobretudo aqueles relativos às minorias.

No ambiente escolar esse traço totalizador, que desqualifica o outro apenas por este se expressar de forma diversa, faz-se ainda mais pernicioso. Toda e qualquer opinião ou expressão subjetiva que destoe daquelas tidas como aceitáveis, desejáveis ou permitidas são prontamente combatidas (às vezes, inclusive, criminalizadas). No bojo deste processo de caça às bruxas, vemos emergir diversos projetos de lei que visam combater, nas escolas, o ensino daquilo que seus propositores entendem como ideologia (de gênero, partidária, religiosa etc.), em uma contraditória busca ideológica da não-ideologia.

Em contrapartida, são notáveis os movimentos de resistência em diversos setores progressistas da sociedade, sobretudo nas escolas. Uma pequena amostra dessas lutas pela garantia de direitos e pelo reconhecimento da multiformidade das expressões humanas pode ser obtida em números anteriores da Revista, dentre os quais destacamos os dossiês (Des)ocupar é resistir? (v.19, nำ e Especial, 2017) e É preciso defender a escola (v.19, no, 2017).

Fiel ao seu escopo editorial multidisciplinar, o primeiro número da Revista ETD Educação Temática Digital de 2018, no qual são publicados apenas artigos de demanda contínua, traz aos leitores e leitoras um conjunto de 15 artigos que reflete a pluralidade de visões, compromissos políticos, horizontes teóricos, engajamentos sociais, metodologias e práticas que, como metáforas, deveriam constituir a riqueza da vida em sociedade.

Esperamos que a leitura, além de agradável, seja um convite à abertura em seu sentido mais amplo, como sinônimo de empatia, alteridade, tolerância e diversidade. 